region beneath hind wings obliquely striate; metathorax closely punctured, the area triangular, strongly, transversely grooved, and with a longitudinal median groove; thorax ferruginous, the mesothorax blackish, suffused with red behind, the area of metathorax black or almost; prothorax above, scutellum anteriorly (narrowest in the middle), postscutellum, a patch on upper part of pleura, and an elongated mark on each side of metathorax, all pale yellow; tegulæ ferruginous; wings hyaline, with a slight cloud near upper end of basal nervure, and a very large dark brown cloud occupying the marginal cell, the apex of the first submarginal, the small second submarginal, the third submarginal except below, and the apical area beyond these; stigma clear orange-ferruginous, nervures fuscous; recurrent nervures received near beginning of second and third submarginal cells; legs bright ferruginous; hind tibiæ with strong but short spines on outer edge; abdomen constricted at the bases of the segments, shining, punctures strong and well separated, but segrnents 2 to 4 with a band of small dense punctures across the middle; first segment small; first four segments reddish-fuscous or reddisn-black above, the others and the venter ferruginous; first five segments each with a broad apical pale yellow band, that on second very broad laterally, but widely emarginate in the middle; pygidial area broad, clull, subrugose.

In Cresson's table of Eucerceris this runs nearest to E. fulvipes, Cress., to which it is allied, but fulvipes has conspicuous light markings on the face, and honey-yellow nervures.

Hab.--Phcenix, Arizona, I897, November. Collector unknown; received from Mr. S. N. Dunning.

\title{
A JULY BLIZZARD.
}

BY WM. H. BROADWELL, NEWARK, N. J.

My duties as a letter carrier necessitate my being out each night till I a.m., so I have a fine chance to observe the things that go on in the entomological world after sundown. As I pass several hundred electric lights in the suburbs, I see and get a large quantity of insects that I would not otherwise come across.

On the evening of July $17^{\text {th }}$ the "blizzard" occurred. From about 8 p.m. until 2 a.m., by actual observation-and no doubt until daylightthere were around each electric light thousands, yes, millions, of a small white molb-Ennomos subsignarius. 
In New York they were in evidence on the $\mathrm{r} 5^{\mathrm{t} h}$, on the $r 6$ th in Paterson, and in Newark on the $\mathrm{I} 7 \mathrm{th}$. At all these places they were present in about the same abundance.

At an electric light two doors away from my house they covered a branch of a tree extending out over the street so thickly that, when standing at my door, the braich had the appearance it would have after a $h \rightarrow n y$ fail of wet, clinging snow. On the front of the two houses nearest to this light, from the top of the first-floor windows to the roof-both three-story houses-you could not have placed your hand on the boards without disturbing four or five moths. There is an eight-foot alley between these houses, and the sides adjoining this alley were covered in the same manner.

When going along the streets and passing a light, one's clothing became coated as fffectually as with real particles of snow. They would fly in one's face, in one's eyes, and into one's mouth if it were not kept tightly shut.

Early the following morning (the i 8 th), under the lamps the wings were on the ground as thick as apple blossoms after a storm, showing that the sparrows had not forgotien why they were brought over to this country some forty years ago. In New York they extended from Herald Square to Harlem. At Paterson and Newark they extended to all parts of the cities.

Although this moth was so abundant, it is as harmless as it is beautiful.

E. subsignarius feeds on only five or six varieties of trees, and except under the most unusual conditions could it do much harm. We may consider ourselves fortunate that the invasion was not of the Brown-tail or Gypsy moths. It would be a hard matter to say where this army of invaders came from, but no doubt conditions somewhere were favourable to their breeding to such an enormous extent.

In July, 1897 or I 898 , I saw a similar phenomenon at Boonton, N. J., but in this case the invaders were Nepytia semiclusaria.

On the 4 th of July I was in a large woods, and suddenly came to a tree completely covered from base to the lower limbs with semiclusaria, and upon going a little further I saw other trees covered as thickly. As in this latest instance the invasion was for only one day, the next day only a dozen or so could be found. Whence came they? Whither do they go? It is easy to answer the last, but who can explain the first? 